\title{
APPLICATION OF REACH AND LCA SYSTEM'S TO THE MATERIALS FORMED IN THE PRODUCTION OF MINERAL WOOL
}

\author{
ZASTOSOWANIE SYSTEMÓW REACH I LCA DLA MATERIAŁÓW \\ POWSTAJĄCYCH W PROCESIE PRODUKCJI WELNY MINERALNEJ
}

\begin{abstract}
The article analyses the application of two management systems - REACH directive and ISO 14040 (Life Cycle Assessment - LCA) with reference to the technological process as well as by-products of mineral wool production. It characterizes basic differences between the norms discussed, i.e. the strict formalization of REACH, which results in the analysis being conducted according to a precisely defined scheme, or the subjective character of LCA, which makes it possible to take into account the most important environmental aspects pertaining to the entire life cycle of a particular product. The discussion provides a basis for formulating the general conclusion that the classification criteria encompassed by REACH regulations do not allow for a complex analysis of the negative environmental impact of a particular substance (preparation, product) and should be complemented with elements of LCA analysis.
\end{abstract}

Keywords: REACH system, ISO 14040 standard, mineral wool

\section{Introduction}

Apart from the positive impact, the currently used chemical substances can also exert a negative influence on health and environment. That is why in recent years we have observed an increased interest in management systems the main aim of which is to minimize the negative effect of substances regarded as arduous to the environment. The legislative works resulted in a regulation passed by the Parliament and Council of the European Union dated $16^{\text {th }}$ December 2006 on Registration, Evaluation and Authorisation of chemicals (REACH) and the establishing of European Chemicals Agency (ECHA), based in Helsinki.

\footnotetext{
${ }^{1}$ Faculty of Mining and Geology, Institute of Applied Geology, Silesian University of Technology, ul. Akademicka 2, 44-100 Gliwice, Poland, phone +48 32237 13 07, email: zdzislaw.adamczyk@polsl.pl

${ }^{2}$ Institute of Engineering and Environmental Protection, Faculty of Materials, Civil and Environmental Engineering, University of Bielsko-Biała, ul. Willowa 2, 43-309 Bielsko-Biała, Poland, phone +48 338279139 , email: aharat@ath.bielsko.pl

${ }^{3}$ Institute of Geological Engineering, Faculty of Mining and Geology, University of Ostrava, 17 Listopadu 15/2172, 70833 Ostrava, Czech Republic, phone +420 5973235 00, email: arnost.grmela@ vsb.cz

*Corresponding author: zdzislaw.adamczyk@polsl.pl
} 
Ecological life cycle assessment (LCA) still remains a relatively new environment management method. However, this regulation, stipulated by ISO 14040 standard, can be considered a very universal one, as its major assumption is striving to take into consideration all the factors related to a particular product (product system) which affect the environment. Life cycle assessment is widely applied as a methodology to quantitatively compare the overall environmental performance of products and systems over their full life cycle looking at various impacts related to chemical emissions and resource use [1]. LCA analysis encompasses a full life cycle of a product, so-called "from cradle to grave", which causes that this analysis should include both the harvesting of resources and the production process, transport, application as well as storage or processing of waste.

Both systems are based on different assumptions. LCA refers to the whole product life cycle, whereas REACH is a formalized system which specifies strict rules to be observed by producers, importers and further users to make sure that the substances they produce, place on the market or use do not have an adverse impact on human health and environment. In consequence, they are obliged to provide ECHA with information regarding physico-chemical, toxicological and eco-toxicological properties, which is required by $\mathrm{REACH}$ and catalogued in the regulation contents.

In this work mineral wool has been subjected to analysis, the example of which has been used to illustrate major differences between REACH regulation and LCA analysis.

\section{Raw materials and technological conditions of the mineral wool production process}

The basic raw materials used for the production of mineral wool are basalts and gabbros. Although tests with other materials, such as waste slug from copper production, have been conducted, they have not gained a foothold for this purpose.

The resources are placed in a shaft furnace and melted until a homogenous mixture is obtained (lava). The fuel in this process is coke. Fluxes are often used in order to lower the melting point, usually dolomite or limestone.

Basalts are rocks of volcanic origin (extrusive rocks) divided into many types. Gabbros, on the other hand, are plutonic in origin (intrusive rocks) and also divided into many types that occur in the Earth's crust. However, used in the production of mineral wool are those types which meet one of the main criteria - chemical composition. Other criteria are also used for the assessment of a material's usability for mineral wool production, though they also rely on the chemical composition of the material. Those criteria include: acidity module, crystallisation capability and viscosity of the alloy from which mineral wool is produced.

After being melted, the lava in the furnace is gravitationally directed to the fiberization machine, whose main element are discs spinning at high speeds, where the lava is fiberized and the resulting fibres are cooled with air. Rapid cooling facilitates the creation of the amorphous phase, so the process is conducted in such a way that mineral components do not crystallise. The fibres formed undergo certain treatment, which facilitates its formation into particular products further on in the technological process (Fig. 1) and allows it to achieve better parameters in terms of insulation.

Before proceeding with lava fiberization, the surplus of iron is removed from the mixture by being tapped from the shaft furnace, as larger contents of iron in the wool 
reduce its technical parameters (brittleness and corrosiveness), which is the reason for the loss of lava mass.

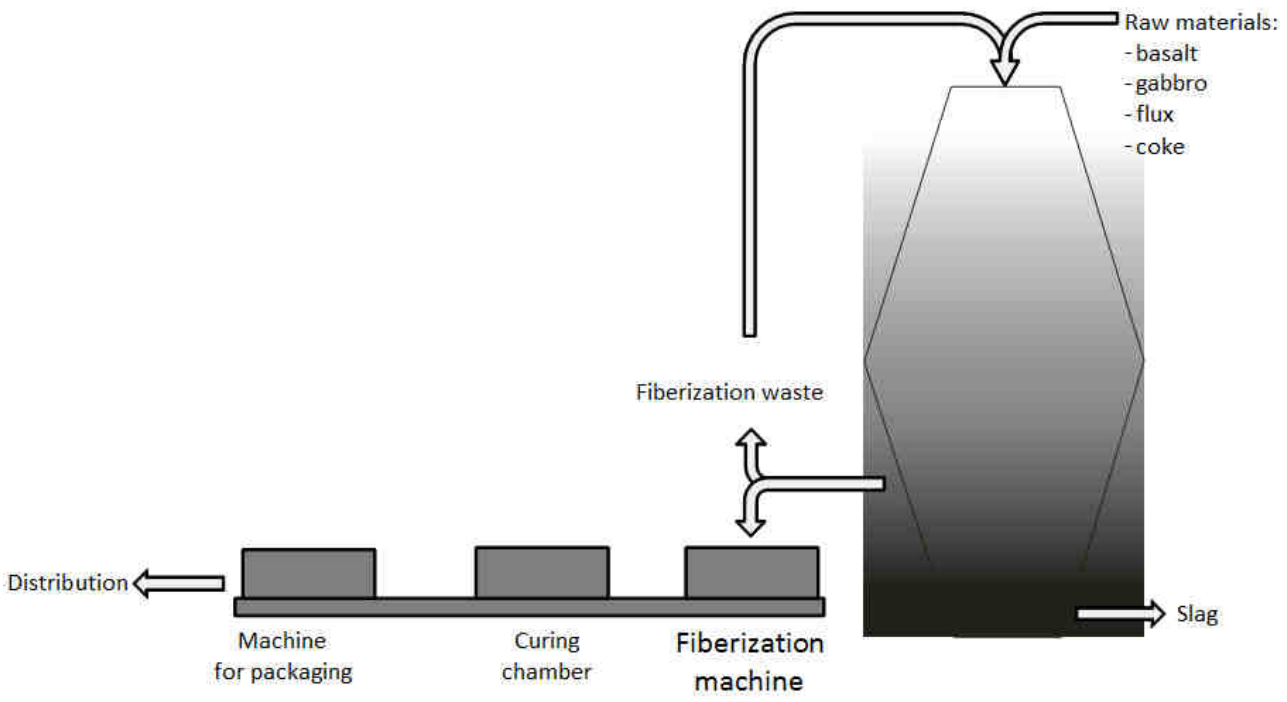

Fig. 1. Technological flow sheet for mineral wool production

In Poland, mineral wool production is based on resources that occur in Lower Silesia. Only a selected few from the multitude of Neogene basalts which occur there meet the criteria for material assessment and are used by companies that specialise in mineral wool manufacturing.

\section{Materials formed in the production process}

Mineral wool is formed into appropriate products and, when packaged, is a final product. Mineral wool consists of artificial mineral fibres with a diameter of 3-6 $\mu \mathrm{m}$, which are built mainly of shapeless silicates (95 to 99\%) and organic binder (phenol-formaldehyde resin water emulsion), which accounts for 1 to $5 \%$ of ingredients. The chemical composition of mineral wool is dominated by silica, the content of which ranges from 35 to $45 \mathrm{wt} . \%$ as well as calcium and magnesium oxides, jointly accounting for 20-30 wt.\% (Table 1). An important component of mineral wool is also clay, the content of which ranges from 15 to 25 wt. $\%$.

Despite fast cooling of the fiberized lava in a fiberization machine, the fibres formed are not fully amorphous. As revealed by Mössbauer spectroscopy investigations [2], mineral wool was found to contain Fe-Ti-Al spinels, ulvospinel, hypersthene and ilmenite.

The structural-textural parameters of final products (mineral wool board or roll) depend on the production process parameters and conditions.

It should be noted that beside the final product two types of waste are produced in the process of mineral wool manufacturing. These are: (i) fiberization waste and (ii) slag.

Fiberization waste is produced from fibres which, instead of reaching the assembly line, fall from the fiberization machine outside the line and are collected in special 
containers. Their chemical and mineral composition is identical with mineral wool produced.

Ranges of contents of major chemical components in mineral wool

\begin{tabular}{|c|c|}
\hline Chemical component & Content W/W [\%] \\
\hline $\mathrm{SiO}_{2}$ & $35-45$ \\
\hline $\mathrm{Al}_{2} \mathrm{O}_{3}$ & $15-25$ \\
\hline $\mathrm{Fe}_{2} \mathrm{O}_{3}$ & $2-11$ \\
\hline $\mathrm{CaO}+\mathrm{MgO}$ & $20-35$ \\
\hline $\mathrm{Na}_{2} \mathrm{O}+\mathrm{K}_{2} \mathrm{O}$ & $1-7$ \\
\hline
\end{tabular}

Slag is produced in the process of iron tap. In structural and textural terms there are two types of slag, i.e. fine-pored and large-pored, which depends on the rate of lava tap cooling (after iron tap), the presence of gaseous components. Its chemical and mineral composition differs significantly from the remaining materials obtained in the process of mineral wool manufacturing and production of fiberization waste. The chemical composition is characterized by a twice higher content of iron compared to mineral wool or fiberization waste. The content of iron in slag is also higher than in the charge. In the mineral composition the following were found: hypersthene, augite, ferro fayalite [2] as well as enstatite, magnetite, metallic iron, glaze, cohenite, iron sulphide.

\section{Use of production process by-products}

Mineral wool, irrespective of its packaging, is used as an insulating material in the building industry.

Due to the chemical and mineral composition, fiberization waste, having been subjected to many procedures (briquetting), is returned to the technological process as a full-value component of charge for shaft furnace (together with raw materials).

Slag, due to its specific chemical and mineral composition as well as the structural-textural nature, is not used, but stored.

\section{Comparative analysis of using the REACH system and LCA standard for mineral wool}

Chemicals present an important case for risk assessment and management due to their importance as building blocks of materials, and to their multiple effects: adverse and beneficial, biophysical and socio-economic. The risks of chemicals to human health and the environment have been often found to be of great concern to people also in the EU [3, 4]. The purpose of REACH is to ensure a high level of protection of human health and the environment, including the promotion of alternative methods for assessment of hazards of substances, as well as the free circulation of substances on internal market while enhancing competitiveness and innovation [5].

It seems that an attempt to conduct a comparative analysis of REACH regulation and an environmental life cycle assessment (LCA) should be focussed on major differences between the environment management systems subjected to analysis.

The discussed standards have a different legal nature, as REACH is a regulation passed by the Parliament and Council of the European Union. It is therefore the highest rank legal 
act of the community law, is binding in its entirety and directly applicable throughout EU member states. This means that the implementation process characteristic of directives does not apply to it. On the other hand, LCA is one of ISO 14000 series standards. This regulation cannot be regarded as a legal standard in the strict sense. For a legal standard always contains 3 elements: a hypothesis, a disposition, disposition and sanction. ISO standards, in principle, address all of them. They do not have a strictly determined catalogue of addressees, and their application is on voluntary basis. As a result, any non-compliance of a particular subject's behaviour with the regulations contained in it does not automatically entail negative consequences for this subject.

LCA can be considered a non-formalized system due to the fact that a person performing an analysis has a large margin of discretion regarding the choice of major criteria of environmental effect according to which an assessment of the impact that a particular substance, preparation or product exerts on the environment will be conducted. As opposed to LCA, REACH system is strictly formalized and, in consequence, imposes the criteria according to which the person conducting an analysis should assess the environmental impact of a given substance, preparation or product. Pursuant to the provisions contained in REACH regulation, the scope of necessary information to be submitted is dependent on the quantity of the substance produced or imported to the community market.

The fact that REACH regulation imposes analysis criteria can result in overlooking the negative environmental effects which are specific of a particular compound, which, in turn, may be included in an LCA analysis due to the freedom of choice. Despite its extent and detail, REACH includes rather limited provisions for integrated assessment of cumulative risks from multiple stressors [6]. REACH regulation completely omits the problems of work environment safety, which is an extremely important element, directly affecting the safety of applying a particular substance. Naturally, there are no obstacles to including this type of analysis in LCA. For obvious reasons, the LCA methodology can be considered more complex and universal than REACH regulation, because it encompasses all the stages of product life cycle, which in literature is referred to as "cradle to grave analysis" [7,8]. Toxicity models in LCA currently only characterize a small fraction of marketed substances, mostly because of limitations in the underlying ecotoxicity data. One approach to improve the current data situation in LCA is to identify new data sources, such as the European Registration, Evaluation, Authorisation, and Restriction of Chemicals database [9].

REACH system is based on 3 pillars - registration, evaluation and authorisation. The first of the above mentioned principles - evaluation, imposes on the producer (importer) of a particular substance the duty to electronically send comprehensive data on the properties of a given substance to ECHA. The assessment procedure involves identifying substances that are particularly dangerous to human life and health, the application of which should be limited. The last of the above mentioned principles - authorisation, refers to substances classified as extremely hazardous. To be placed on the market, these products require a special permit issued by the European Commission.

Due to the fact that mineral wool belongs to extremely hazardous substances (preparations, products), in practice only the registration procedure specified by the above mentioned REACH regulation is applied. It imposes on the producer (importer) the obligation to submit physical-chemical, toxicological and eco-toxicological properties of a product. 
The required information regarding the substance physico-chemcial properties include in particular: state of matter, melting temperature (solidifying point, boiling point), relative density, vapour pressure, surface tension, water solubility, flammability, explosive properties, self-ignition temperature, oxidizing properties and granulometry. On the other hand, major toxicological toxicological and eco-toxicological properties to be submitted include: skin and eye irritation effect (corrosive, allergic), mutagenicity, acute toxicity, water environmental impact and substance decomposition in the environment. The overall conclusion in accordance with the $\mathrm{REACH}$ regulation is that there are no hazardous classifications associated with mineral wool fibres in respect to physical, health and environmental considerations [10].

Based on the above information required by $\mathrm{REACH}$, the information submitted by producers (importers), ECHA creates a uniform database containing physico-chemical, toxicological and eco-toxicological properties of substances. However, it should be emphasized that so created information database, apart from numerous advantages, which enable in particular conducting analyses of the effect exerted by given substances, is encumbered with some imperfections. The major one is the scope of submitted information. Pursuant to art. 2 paragraph 2 of REACH regulation, waste is not a substance, preparation or product in view of its provisions. As a result, REACH regulations overlook waste procedures, which, in turn, is a crucial part of LCA analysis.

As mentioned before, fiberization waste and slag are by-products of the production process. The former is returned to the technological process, whereas slag is stored. This waste storage should not cause migration of contamination to the environment. Table 2 presents the results of washability test conducted for fiberization waste and slag.

Table 2

Washability test results

\begin{tabular}{|c|c|c|c|}
\hline Component & $\begin{array}{c}\text { Limit value } \\
{\left[\mathrm{mg} / \mathbf{d m}^{3}\right]}\end{array}$ & $\begin{array}{l}\text { Value in fiberization waste } \\
{\left[\mathrm{mg} / \mathrm{dm}^{3}\right]}\end{array}$ & $\begin{array}{c}\text { Value in slag } \\
{\left[\mathrm{mg} / \mathrm{dm}^{3}\right]}\end{array}$ \\
\hline $\mathrm{SO}_{4}{ }^{2-}$ & 500 & $<10.0$ & $<10.0$ \\
\hline $\mathrm{Cl}^{-}$ & 1000 & $<3.5$ & $<3.5$ \\
\hline $\mathrm{Na}^{+}$ & 800 & 0.9 & 4.1 \\
\hline $\mathrm{K}^{+}$ & 80 & 0.6 & 1.4 \\
\hline $\mathrm{Fe}$ & 10.0 & 0.05 & $<0.02$ \\
\hline
\end{tabular}

Based on the data contained in Table 2, it can be concluded that waste storage at landfill sites should not cause migration of contamination to the environment. It should be noted that the washability test, the results of which have been presented, was conducted under laboratory conditions. In the case of waste dump conditions, especially when the process of infiltration is taken into consideration, it should be presumed that the real values of the discussed parameters will be higher. This applies in particular to iron, which is characterized by considerable mobility under hypergenic conditions.

It seems that including elements of both LCA methodology and REACH regulation can give excellent results in overall assessment of a substance (preparation or product) environmental impact. This way a comprehensive and all-encompassing evaluation can be obtained. Moreover, combination of LCA and REACH criteria can strengthen and systemize the assessment of negative impact conducted by LCA method [11]. Inclusion of $\mathrm{REACH}$ and LCA elements in one analysis is an excellent example of how the principle of 
sustainable development can be implemented in practice, as it will combine economic effectiveness with respect and protection of environment and its resources.

\section{Conclusions}

The analyses conducted in the study provide a basis for concluding as follows:

- implementation of REACH regulation entails the necessity to modify production technology and using environment-friendly substances in the process,

- $\quad$ substance classification criteria stipulated by REACH regulation are insufficient for conducting a comprehensive assessment of their safe use,

- it is therefore recommended that $\mathrm{REACH}$ regulation requirements should be complemented, in particular in terms of waste, with elements of environmental life cycle assessment (LCA).

\section{References}

[1] International Organization for Standardization. Environmental Management-Life cycle assessment. Principles and framework. ISO 14040:2006 International Standard. Geneva, Switzerland. https://www.iso.org/obp/ui/\#iso:std:iso:14040:ed-2:v1:en, access: 28.11.2016.

[2] Adamczyk Z, Komraus J. An investigation of distribution of iron compounds in rock wool production. Mater Manuf Process. 2001;16(6):577-587. DOI: 10.1081/AMP-100108528.

[3] Verbeke W, Frewer LJ, Scholderer J, De Brabander HF. Why consumers behave as they do with respect to food safety and risk information. Anal Chim Acta. 2007;586(1-2):2-7. DOI: 10.1016/j.aca.2006.07.065.

[4] Pluhar ZF, Piko BF, Kovacs S, Uzzoli A. Air pollution is bad for my health: Hungarian children's knowledge of the role of environment in health and disease. Health Place. 2009;15(1):239-46. DOI: 10.1016/j.healthplace.2008.05.005.

[5] Regulation (EC) No 1907/2006 of the European Parliament and of the Council of 18 December 2006 concerning the Registration, Evaluation, Authorisation and Restriction of Chemicals (REACH), establishing a European Chemicals Agency, amending Directive 1999/45/EC and repealing Council Regulation (EEC) No 793/93 and Commission Regulation (EC) No 1488/94 as well as Council Directive 76/769/ EEC and Commission Directives 91/155/EEC, 93/67/EEC, 93/105/EC and 2000/21/EC. Official J EU L 2006b;396(1):849. http://eurlex.europa.eu/LexUriServ/LexUriServ.do?uri= OJ:L:2007:136:0003:0280:en:PDF, access: 23.11.2016.

[6] Assmuth T, Hildén M, Craye M. Beyond REACH: Roadblocks and shortcuts en route to integrated risk assessment and management of chemicals. Sci Total Environ. 2010;408(18):3954-3963. DOI: 10.1016/scitotenv.2010.02.010.

[7] Bahr B, Steen B. Reducing epistemological uncertainty in life cycle inventory. J Clean Prod. 2004;12:369-388. DOI: 10.1016/S0959-6526(02)00197-X.

[8] Christensen FM, Olsen SI. The potential role of life cycle assessment in regulation of chemicals in the European Union. Int J Life Cycle Assess. 2004;9(5):327-332. DOI: 10.1007/bf02979422.

[9] Müller N, de Zwart D, Hauschild M, Kijko G, Fantke P. Exploring REACH as a potential data source for characterizing ecotoxicity in life cycle assessment. Environ Toxicol Chem. 2016;36(2):1-9. DOI: 10.1002/etc.3542.

[10] Rockwool, Safety Data Sheet. http://www.roxul-rti.com/files/RTI/New_Website/2_Tools_and_Downloads/ SUIS/RTI\%20SUIS\%20update\%20October\%202014_Int\%20ENG.pdf, access: 25.11.2016.

[11] Askham C. REACH and LCA - Methodological Approaches and Challenges. Int J Life Cycle Assess. 2012;17(1):43-57. DOI: 10.1007/s11367-011-0329-z. 


\title{
ZASTOSOWANIE SYSTEMÓW REACH I LCA DLA MATERIAŁÓW POWSTAJĄCYCH W PROCESIE PRODUKCJI WELNY MIN ERALNEJ
}

\author{
${ }^{1}$ Wydział Górnictwa i Geologii, Politechnika Śląska, Gliwice \\ ${ }^{2}$ Wydział Inżynierii Materiałów, Budownictwa i Środowiska, Akademia Techniczno-Humanistyczna \\ w Bielsku-Białej \\ ${ }^{3}$ Wydział Górnictwa i Geologii, Uniwersytet Techniczny w Ostrawie, Republika Czeska
}

\begin{abstract}
Abstrakt: W pracy analizie poddano zastosowanie dwóch systemów zarządzania - rozporządzenia REACH oraz normy ISO 14040 (Środowiskowego Cyklu Życia Produktu - LCA) w odniesieniu do procesu technologicznego wytwarzania, jak również odpadów powstających w procesie produkcji wełny mineralnej. Scharakteryzowano podstawowe różnice występujące między omawianymi normami, tj. ścisłe sformalizowanie REACH, którego konsekwencją jest dokonywanie analizy według ściśle określonego schematu, oraz subiektywny charakter LCA, pozwalający na uwzględnienie najważniejszych aspektów środowiskowych, odnoszących się do pełnego cyklu życia określonego wyrobu. Przeprowadzone rozważania dają podstawę do sformułowania generalnego wniosku, wskazującego, iż kryteria klasyfikacyjne ujęte przez przepisy rozporządzenia REACH nie pozwalają na kompleksową analizę negatywnych oddziaływań środowiskowych określonej substancji (preparatu, wyrobu) i powinny zostać uzupełnione o elementy analizy LCA.
\end{abstract}

Słowa kluczowe: system REACH, norma ISO 14040, wełna mineralna 